\title{
ANALISIS SISTEM PEMBERIAN KREDIT PROGRAM KEMITRAAN BINA LINGKUNGAN DI PT JASA RAHARJA PERSERO SULUT
}

\author{
Jessica Ch Kaunang ${ }^{1}$, Harijanto Sabijono ${ }^{2}$, Anneke Wangkar ${ }^{3}$ \\ ${ }^{1,2,3}$ Fakultas Ekonomi dan Bisnis, Jurusan Akuntansi, Universitas Sam Ratulangi, Jl. Kampus Bahu, Manado, \\ 95115, Indonesia \\ E-mail : jkaunang76@gmail.com
}

\begin{abstract}
Development in the field of economics is an objective to be achieved in implementing economic development programs, including the partnership program implemented by state enterprises to small businesses. The partneship program is a CSR program of SOEs as a concern to the community. This research done on the basis of program Kemitraan Bina Lingkungan (PKBL) conducted by PT Jasa Raharja Persero Manado, that aims to prevent the occurrence of non performing loans for micro and small business credit. The kind of research used is descriptitive qualitative. Preventive measures undertaken doing by visiting for every three months.

Keywords: System and procedure of credit, micro and small business credit, Non performing loans.
\end{abstract}

\section{PENDAHULUAN}

Dalam mengembangkan pertumbuhan perekonomian nasional, pemerintah sangat mengharapkan partisipasi usaha swasta. Sebagai salah satu langkah kebijakannya, pemerintah memusatkan perhatiaanya pada pembinaan dan pengembangan sektor usaha swasta dalam skala kecil dan menengah, karena keberhasilan sektor ini dapat dijadikan salah satu landasan yang kuat menopang laju pertumbuhan ekonomi nasional. Usaha kecil yang merupakan bagian integral dunia usaha nasional mempunyai kedudukan, potensi dan peranan yang sangat penting dan strategis dalam mewujudkan tujuan pembangunan nasional pada umumnya dan tujuan pembangunan ekonomi pada khususnya. Usaha kecil merupakan kegiatan usaha yang mampu memperluas lapangan kerja dan memberikan pelayanan ekonomi yang luas pada masyarakat dapat berperan dalam proses pemerataan dan peningkatan pendapatan masyarakat, serta mendorong pertumbuhan ekonomi.

Atas dasar kenyataan tersebut pemerintah menghimbau kepada seluruh Badan Usaha Milik Negara (BUMN) untuk melaksanakan dasar program pembinaan pengusaha kecil dalam program kemitraan bina lingkungan melalui surat edaran menteri BUMN nomor 09/MBU/VII/2015 tertanggal 3 Juli 2015. "BUMN tidak hanya bertujuan unutk mencari keuntungan (profit)tetapi juga memiliki tanggung jawab terhadap karyawannya dalam memberikanbimbingan aktif dan pengusaha yang tergolong lemah,koperasi, dan masyarakat serta dalam pelestarian lingkungan. (Aritonang, 2013). Dengan adanya keputusan tersebut pada saat ini seluruh BUMN diwajibkan menyisihkan keuntungan dari usahanya 2\% laba untuk disalurkan kepada pengusaha kecil dan koperasi. PT Jasa Raharja Persero merupakan salah satu BUMN yang melakukan program usaha kemitraan untuk mendukung usaha utamanya dibidang jasa asuransi kecelakaan. Defersifikasi usaha dan pendirian program kemitraan tersebut didasarkan pada Keputusan Menteri BUMN Nomor 05/MBU/2007 dengan revisi terbaru surat keputusan Menteri BUMN nomor 09/MBU/VII/2015 tertanggal 3 Juli 2015 tentang Program Kemitraan Bina Lingkungan (PKBL) yang lebih komprehensif dan sesuai dengan perkembangan ekonomi dan kondisi di lingkungan sosial masyarakat sekitar BUMN. Dalam hal ini BUMN ditunjuk sebagai pelaksana program kemitraan 
dikarenakan seluruh atau sebagian besar modalnya berasal dari kekayaan negara yang dipisahkan menurut barang dan jasa.

Sistem pemberian kredit program kemitraan bina lingkunngan merupakakan program pemberian kredit yang ada di PT Jasa Raharja Persero Sulut. Selain usaha utamanya yang bergerak dalam asuransi kecelakaan dan transportasi. Sebanyak 100 mitra binaan yang berhasil mendapatkan pinjaman dari unit Program Kemitraan Bina Lingkungan dari tahun 2014-2016 dengan tingkat pengembalian pinjaman rata-rata 59,55\%. Dana yang dikeluarkan Jasa Raharja selaku BUMN pembina adalah sebesar Rp.2.285.000.000,- dari tahun 20142016 dengan tingkat pengembalian yang digolongkan kredit macet sangat besar yaitu sebesar $>5.000 .000 .000,-$. Fenomena yang dihadapi oleh BUMN pembina dalam pembinaan usaha kecil dan koperasi adalah terbatasnya dana yang tersedia dibandingkan dengan banyaknya permohonan yang masuk dan sulitnya menentukan usaha kecil dan koperasi akan dibina. Apabila terjadi resiko kemacetan pinjaman akan menghambat program pemberian bantuan kepada mitra binaan yang lain karena dana hasil pengembalian akan disalurkan kembali untuk pemberian pinjaman kepada usaha kecil agar dan koperasi lainnya (dana bergulir). Berdasarkan masalah yang telah diuraikan, maka tujuan dari penelitian ini adalah Untuk mengetahui dan menganalisis tingkat pengembalian pinjaman pemberian kredit program kemitraan bina lingkungan pada usaha mikro kecil menengah.

\section{TINJAUAN PUSTAKA}

\subsection{Konsep Akuntansi}

Akuntansi adalah seni pencatatan, pengklasifikasian, dan pengikthisaran dalam cara yang signifikan dan satuan mata uang, transaksi-transaksi dan kejadian-kejadian yang paling tidak sebagian diantaranya, memiliki sifat keuangan, dan selanjutnya menginterpretasikan hasilnya (American institute of certified Public Accountants dalam Belkaoui, 2015:50).

\subsection{Konsep Akuntansi Keuangan}

Akuntansi keuangan adalah bagian dari akuntansi yang menyediakan informasi ekonomi dan informasi keuangan kepada investor, kreditor, dan pengguna eksternal lainnya (Weygant, et al 2015;6). Akuntansi keuangan merupakan bidang akuntansi yang menyediakan informasi akuntansi secara umum bagi para pemakai atau pengambil keputusan yang ada di luar organisasi. Akuntansi keuangan (financial accounting) sangat terkait dengan pencatatan dan pelaporan data dari aktivitas ekonomi suatu perushaan (Reeve, et al 2013;10).

\subsection{Corporate Social Responsibility (CSR)}

\subsubsection{Dimensi-Dimensi CSR}

CSR terdiri dari empat dimensi yaitu ekonomi (economic), hukum (legal), etika (ethical), dan kemanusiaan (philanthropic) yang digambarkan dalam bentuk piramida. Keempat dimensi CSR tersebut adalah sebagai berikut:

1. Tanggung jawab ekonomi

Tanggung jawab ekonomi adalah tanggung jawab sosial perbankan yang utama dan yang paling penting merupakan pondasi dasar dari ketiga tanggung jawab untuk menyediakan barang atau jasa yang diingginkan masyarakat dan menjualnya demi memperoleh keuntungan.

2. Tanggung jawab hukum

Tanggung jawab hukum semata-mata berhubungan dengan tanggung jawab ekonomi dan mencerminkan ekspekatasi masyarakat terhadap perusahaan untuk memenuhi tugas ekonominya dengan batasan yang diatur oleh oleh hukum.

3. Tanggung jawab Etika

Tanggung jawab etika dari perusahaan meliputi segala aktivitas dab praktik yang diharapkan atau dilarang oleh masyarakat meskipun hal tersebut tidak diatur oleh 
hukum. Dalam hal ini perusahaan memiliki kewenangan utnuk menghindari hal-hal yang merugikan dan melakukan apa yang benar, tepat, dan wajar.

4. Tanggung Jawab Kemanusiaan

Tanggung jawab kemanusiaan menyangkut segala sesuatu yang tidak diamanatkan secara nyata oleh masyarakat, yang bergantung pada keputusan secara nyata oleh masyarakat, yang bergantung pada keputusan dan pilihan masing-masing. Meskipun demikian, perusahaan diharapkan untuk memberikan kontribusi keuangan dan SDM untuk masyarakat dan meningkatkan kualitas kehidupannya.

\subsection{Program Kemitraan}

Program kemitraan adalah program untuk meningkatkan usaha kecil sebagai mitra binaan agar menjadi tangguh dan mandiri sehingga dapat meningkatkan taraf hidup masyarakat melalui pemanfaatan dana dari bagian laba Badan Usaha Milik Negara.

Kemitraan merupakan hubungan kerjasama usaha diberbagai pihak sinergis, bersifat sukarela, dan berdasarkan pinsip saling membutuhkan, saling mendukung, dan saling menguntungkan dengan disertai pembinaan dan pengembangan UKM oleh usaha besar. (Rachmat 2004;40)

\subsubsection{Tujuan Kemitraan}

Tujuan dilakukannya program kemitraan adalah sebagai berikut:

1. Meningkatkan pendapatan Usaha kecil dan Masyarakat

2. Meningkatkan perolehan nilai tambah bagi pelaku kemitraan

3. Menigkatkan pemerataan dan pemberdayaan masyarakat

4. Meningkatkan pertumbuhan ekonomi pedesaan wilayah dan nasional

5. Memperluas kesempatan kerja

6. Meningkatkan ketahanan ekonomi nasional

\subsubsection{Jenis-Jenis Kemitraan}

Beberapa jenis-jenis kemitraan diantaranya adalah sebagai berikut:

1. Inti plasma

Inti plasma berfungsi melakukan pembinaan, peyediaan sarana produksi, bimbingan teknis, dan pemasaran, sedangkan plasma melakukan fungsi produksi

2. Sub kontrak

Pola ini merujuk pada usaha kecil memproduksi komponen yang diperluas oleh usaha dan besar sebagai bagian dari produksinya. Sedangkan usaha menengah dan besar berfungsi melakukan pembelian komponen dari usaha kecil untuk keperluan produksinya.

3. Dagang umum

Pada pola ini usaha menengah dan besar memasarkan hasil produksi usaha atau usaha kecil sebagai pemasok.

4. Waralaba Pemberian

Waralaba memberikan hak penguasaan lisensi merek dagang dan saluran distribusi perusahaannya kepada penerima waralaba.

5. Keagenan

Pola keagenan merupakan salah satu bentuk hubungan kemitraan dimana usaha kecil diberikan hak khusus untuk memasarkan barang dan jasa.

\subsubsection{Program Kemitraan sebagai wadah UKM}

Program kemitraan merupakan wadah untuk pengembangan UKM dikarenakan program ini dapat menjawab dan mengatasi kelemahan-kelemahan yang selama ini dialami oleh UKM di Indonesia mengingat mekanisme dan struktur kelembagaan kemitraan diatur berdasarkan KEP-2361MBU/2003 yang merupakan peraturan yang keluar dikarenakan peraturan sebelumnya belum dapat memenuhi harapan pelaku UKM. Agar tujuan 
pelaksanaan program kemitraan dapat tercapai maka unit program kemitraan sekurangkurangnya melakukan fungsi pembinaan, evaluasi, penyaluran, penagihan, pelatihan, monitoring, promosi, fungsi administrasi dan keuangan. Unit kemitraan bertanggung jawab kepada salah satu anggota direksi yang ditetapkan dalam rapat direksi. Karyawan yang ditunjuk untuk menangani init program kemitraan BUMN pembina yang bersangkutan.

\subsubsection{Bentuk-bentuk program Kemitraan}

Bentuk pemberian pinjaman yaitu sebagai berikut:

1. Pinjaman untuk modal kerja dan untuk pembelian barang-barang modal (aktiva tetap produktif) seperti mesin dan alat produksi, alat bantu produksi, dan lain sebagainya yang dapat meningkatkan produksi dan penjualan produk mitra binaan

2. Pinjaman khusus yaitu pemberian pinjaman yang dapat diberikan oleh BUMN pembina bersifat jangka pendek dengan wkatu maksimum satu tahun serta dengan nilai pinjaman yang cukup material bagi mitra binaan.

3. Hibah

4. Meningkatkan pengendalian mutu produksi

5. Meningkatkan pemenuhan standarisasi teknologi

6. Meningkatkan rancang bangun dan perekayasaan

7. Bantuan pemasaran produk

\subsection{Penelitian Terdahulu}

Penelitian terdahulu ini menjadi salah satu acuan peneliti dalam melakukan penelitian sehingga peneliti dapat memperkaya teori yang dapat digunakan dalam mengkaji penelitian yang dilakukan peneliti yaitu Keni Kaniawati, Fitria Lilyana, Iwan Rijayana (2016) dengan judul Analisis Penyaluran Kredit pada perkembangan UKM melalui program kemitraan dan bina lingkungan PT Pertamina persero Pemasaran III cab Bandung jenis penelitian kuantitatif hasil penelitian Mitra binaan PT Pertamina Persero mengalami perkembangan usaha dilihat dari kenaikan laba setelah menerima kredit dari PT Pertamina (Persero) unit pemasaran II Bandung dengan persamaan peneliti sama-sama meneliti analisis penyaluran kredit UKM melalui program kemitraan. Perbedaannya terletak pada objek dan metode analisis yang digunakan.

\section{METODE PENELITIAN}

\subsection{Jenis dan sumber data}

Metode penelitian yang digunakan dalam penelitian ini adalah penelitian kualitatif. Menurut Sedarmayanti \& Hidayat (2011: 33) penelitian deskriptif adalah suatu metode dalam pencarian fakta status sekelompok manusia, suatu objek, suatu kondisi, suatu sistem pemikiran ataupun suatu peristiwa pada masa sekarang dengan interpretasi yang tepat. Sedangkan Suryabrata (2013: 75) penelitian deskriptif merupakan jenis penelitian yang tujuannya untuk membuat gambaran secara sistematis, faktual, dan akurat mengenai faktafakta dan sifat-sifat populasi atau daerah tertentu.

\subsection{Metode analisis}

Metode analisis data yang digunakan dalam penelitian ini adalah metode deskriptif. Tujuan dari penelitian deskriptif ini adalah untuk membuat deskipsi, gambaran atau lukisan secara sistematis, faktual dan akurat mengenai fakta-fakta, sifat-sifat serta hubungan antar fenomena yang diselidiki. 


\section{HASIL PENELITIAN DAN PEMBAHASAN}

\subsection{Hasil Penelitian}

\section{Dana Program Kemitraan}

berikut :

Penggunaan dana Program Kemitraan dan Program Bina Lingkungan adalah sebagai

Dana program kemitraan PT Jasa Raharja Persero diberikan dalam bentuk :

a. Pinjaman untuk membiayai modal kerja dan/ atau untuk pembelian barang-barang modal (aset tetap produktif) seperti mesin dan alat produksi, alat bantu produksi, dan lain sebagainya yang dapat meningkatkan produksi dan penjualan produk mitra binaan, yang diprioritaskan untuk :

1. Usaha kecil yang belum memiliki akses perbankan

2. Usaha kecil yang tidak memiliki kaitan usaha dengan BUMN pembina namun diupayakan ke arah terwujudnya keterkaitan usaha

b. Pinjaman Khusus untuk membiayai kebutuhan dana pelaksanaan kegiatan usaha mitra binaan yang bersifat tambahan dan berjangka pendek dalam rangka memenuhi pesanan dari rekanan usaha Mitra binaan.

c. Beban pembinaan terdiri dari

Bantuan pendidikan dan pelatihan serta magang untuk mitra binaan dalam rangka :

1. Meningkatkan keterampilan manajerial dan teknik produksi/ pengolahan

2. Meningkatkan pengendalian mutu produksi

3. Meningkatkan pemenuhan standarisasi teknologi

4. Meningkatkan rancang bangun dan perekayasaan

5. Bantuan pendidikan dan pelatihan serta pemagangan untuk mitra binaan dapat dilakukan sendiri oleh PT Jasa Raharja (Persero) atau menyediakan tenaga penyuluh yang berasal dari lembaga pendidikan/ pealtihan swasta profesional maupun perguruan tinggi

6. Bantuan pemasaran produk mitra binaan, dalam bentuk :

7. Membantu penjualan produk mitra binaan

8. Membantu mempromosikan produk mitra binaan melalui kegiatan pameran Jangka waktu atau masa pembinaan untuk mitra binaan dapat dilakukan terus menerus sampai mitra binaan tersebut menjadi tangguh, mandiri, dan bankable

Beban pembinaan bersifat hibah dan ditetapkan maksimal 20\% dari dana program kemitraan yang disalurkan pada tahun berjalan. Beban pembinaan hanya dapat diberikan kepada atau untuk kepentingan mitra binaan.

\section{Dana Program Bina Lingkungan}

Dana program bina lingkungan digunakan unutk tujuan yang memberikan manfaat kepada masyarakat di wilayah usaha PT Jasa Raharja Persero yang kegiatannya meliputi :

a) Bantuan korban bencana alam, yaitu bantuan yang diberikan untuk meringankan beban para korban yang diakibatkan bencana alam (force majeur)

b) Bantuan pendidikan dan/ atau pelatihan, yaitu bantuan yang diberikan dalam rangka meningkatkan kualitas sumber daya manusia (SDM)

c) Bantuan peningkatan kesehatan, yaitu bantuan yang diberikan dalam rangka meningkatkannkualitas kesehatan masyarakat

d) Bantuan pengembangan prasarana dan sarana umum, yaitu bantuan yang diberikan dalam rangka meningkatkan fasilitas kesejahteraan masyarakat

e) Bantuan sarana ibadah, yaitu bantuan untuk meningkatkan kualitas sarana ibadah masyarakat

f) Bantuan pelestarian alam, yaitu bantuan yang diberikan dalam rangka mendukung pelestarian alam 


\subsubsection{Ketentuan Peyaluran Dana program Kemitraan}

Kualitas pinjaman yang berasal dari dana Program Kemitraan dinilai berdasarkan ketepatan waktu pembayaran pokok dan jasa administrasi pinjaman mitra binaan. Jika mitra binaan hanya membayar sebagian angsuran, maka pembayaran tersebut terlebih dahulu diperhitungkan sebagai pembayaran jasa administrasi pinjaman, dan sisanya (bila ada) untuk pembayaran pokok pinjaman. Ketentuan Penyaluran dana Program kemitraan di PT Jasa Raharja Persero adalah sebagai berikut:

1. Dana program kemitraan disalurkan dalam bentuk :

Pinjaman untuk membiayai modal kerja dan atau pembelian aset dalam rangka meningkatkan produksi dan penjualan mitra binaan

Pinjaman tambahan untuk membiayai kebutuhan yang bersifat jangka pendek dalanm rangka memenuhi pesanan dari rekanan usaha mitra binaan

a) Jumlah pinjaman untuk setiap mitra binaan dari program kemitraan mengacu kepada peraturan Menteri Badan Usaha Milik Negara yang berlaku dan terbaru, serta ketentuan PT Jasa Raharja persero

b) Wewenang otorisasi persetujuan pemberian pinjaman Program Kemitraan akan mengacu kepada ketentuan PT Jasa Raharja Persero yang berlaku

c) Persyaratan untuk setiap Mitra Binaan dari Program Kemitraan mengacu kepada Peraturan Menteri Badan usaha Milik Negara yang berlaku dan terbaru, serta ketentuan PT Jasa Raharja Persero. Persyaratan Calon Mitra Binaan dijabarkan dalam Standar Operasi Seleksi Calon Mitra Binaan

d) Unit PKBL harus melakukan pemantauan terhadap perkembangan Mitra Binaan, paling lambat setiap 6 bulan.

e) Besarnya jasa administrasi pinjaman dana Program kemitraan ditetapkan satu kali pada saat pemberian pinjaman dengan mengacu kepada Peraturan Menteri Badan Usaha Milik Negara dan sesuai dengan kebijakan PT Jasa Raharja Persero

f) Penggolongan Kualitas Pinjaman ditetapkan sebagai berikut:

1. Lancar, adalah pembayaran angsuran pokok dan jasa administrasi pinjaman tepat waktu atau terjadi keterlambatan pembayaran angsuran pokok dan atau jasa administrasi pinjaman selambat-lambatnya 30 hari dari tanggal jatuh tempo pembayaran angsuran, sesuai dengan perjanjian yang telah disetujui bersama.

2. Kurang lancar, apabila terjadi keterlambatan pembayaran angsuran pokok dan atau jasa administrasi pinjaman yang telah melampaui 30 hari dan belum melampaui 180 hari dari tanggal jatuh tempo pembayaran angsuran, sesuai dengan perjanjian yang telah disetujui bersama.

3. Diragukan, apabila terjadi keterlambatan pembayaran angsuran pokok dan atau jasa administrasi pinjaman yang telah melampaui 180 hari dan belum melampaui 270 hari dari tanggal jatuh tempo pembayaran angsuran, sesuai dengan perjanjian yang telah disetujui bersama.

4. Macet, apabila terjadi keterlambatan pembayaran angsuran pokok dan atau jasa administrasi pinjaman yang telah melampaui 270 hari dari tanggal ajtuh tempo pembayaran angsuran, sesuai dengan perjanjian yang telah disetujui bersama.

Pinjaman dengan kualitas kurang lancar, diragukan, dan macet, dapat dilakukan usahausaha pemulihan pinjaman dengan cara menjadwalkan kembali (reschedulling) atau penyesuaian persyaratan (reconditioning). Tindakan penyesuaian persyaratan (reconditioning) dilakukan setelah adanya tindakan penjadwalan kembali (reschedulling). Tidakan pemulihan pinjaman dapat dilakukan apabila memnuhi kriteria sebagai berikut:

a. Mitra binaan beritikad baik dan kooperatif terhadap upaya penyelamatan yang akan dilakukan

b. Usaha mitra binaan masih berjalan dan memiliki prospek usaha 
c. Mitra binaan masih memiliki kemampuan untuk membayar angsuran

Jika dilakukan tindakan penyesuaian persyaratan (reconditioning) terhadap suatu pinjaman, tunggakan jasa administrasi pinjaman dan atau beban jasa administrasi pinjaman selanjutnya yang belum jatuh tempo dapat dihapuskan..

Pinjaman macet yang telah diupayakan pemulihannya, namun tidak berhasil terpulihkan, direklasifikasi menjadi kelompok aktiva lain-lain dengan pos pinjaman bermasalah Tata cara penghapusan pinjaman bermasalah tersebut akn diatur lebih lanjut oleh menteri. Pinjaman bermasalah yang telah dihapus bukuan harus tetap diupayakan penagihannya. Apabila pinjaman bermasalah tersebut berhasil ditagih kembali, hasilnya dicatat dalam pos pinjaman bermasalah dan pinjaman bermasalah yang diterima kembali harus dilaporkan secara periodik dalam laporan triwulan.

\subsection{Pembahasan}

Dari aktivitas pemberian kredit Program Kemitraan Bina Lingkungan muncul piutang usaha bagi perusahaan dimana piutang merupakan aktiva lancar dan merupakan bagian besar dari modal kerja PKBL PT Jasa Raharja Persero Sulut. Piutang usaha yang muncul merupakan harta perusahaan yang harus dijaga dengan baik, hal tersebut dinilai penting karena berasal dari aktivitas pemberian kredit. Resiko yang harus ditanggung perusahaan pun begitu besar dimana bisa terjadi kredit macet yang bisa menurunkan performa unit PKBL menurun. Adanya sistem dan prosedur pemberian kredit yang menggambarkan bahwa sistem pemberian kredit di PKBL Jasa Raharja Persero Sulut sudah baik, sehingga pihak BUMN pembina mengetahui riwayat pinjaman debitur apakah sudah ada akses meminjam kepada bank sebelum kredit diberikan.Adanya prosedur credit analysis yang ketat menjelaskan bahwa sistem pemberian kredit telah diupayakan dengan baik oleh PKBL Jasa Raharja Persero Sulut selaku BUMN pembina, Kasmir (2015:83) pemberian kredit tanpa dianalisis terlebih dahulu akan sangat membahayakan, nasabah dalam hal ini dengan mudah memberikan data-data fiktif sehingga kredit sebenarnya tidak layak diberikan. Credit analysis dijalankan oleh orang-orang berkompeten dan menerapkan prisip 5C, pemilihan calon debitur pun lebih selektif. Hal ini dibuktikan dengan penyertaan dokumen-dokumen terkait yang disyaratkan oleh pihak Jasa Raharja unit PKBL, penyertaan dokumen-dokumen tersebut dimaksudkan untuk mendapat gambaran tentang karakterisitik debitur, agunan, dan usaha sebelum kredit diberikan. Sementara untuk penentuan jenis collateral/agunan PT Jasa Raharja Persero memberikan agunan bergerak maupun tidak bergerak. Ini membuktikan bahwa sistem pemberian kredit di unit PKBL Jasa Raharja Persero Sulut dijalankan dengan sitem prosedur yang baik.

Dalam sistem pemberian kredit yang dilaksanakan PKBL Jasa Raharja Persero Sulut mucul piutang usaha dari aktivitas pemberian kredit unit PKBL. Tabel 4.1 dibawah ini mendekripsikan dari tahun 2014-2016 berapa jumlah dana keseluruhan yang disalurkan kepada mitra binaan. 
Tabel 4.1

Jumlah Mitra Binaan dan dana PKBL tahun 2014-2016 PT Jasa Raharja Persero Sulut

\begin{tabular}{|c|c|c|}
\hline Tahun & Jumlah Mitra Binaan & Dana yg disalurkan \\
\hline 2014 & 25 Mitra Binaan & Rp 600.000.000,- \\
\hline 2015 & 39 Mitra Binaan & $\operatorname{Rp~935.000.000,-~}$ \\
\hline 2016 & 36 Mitra Binaan & $\operatorname{Rp~750.000.000,-~}$ \\
\hline
\end{tabular}

Sumber: PKBL PT Jasa Raharja Persero Sulut (Data Olahan)

Jurnal untuk mencatat transaksi pada saat penyaluran dana kepada mitra binaan adalah sebagai berikut :

\begin{tabular}{|rc|}
\hline $\begin{array}{r}\text { Penyaluran Program Kemitraan } \\
\text { Anggaran Program Kemitraan }\end{array}$ & xxx \\
& \\
\hline
\end{tabular}

Jika dilakukan tindakan penyesuaian persyaratan terhadap suatu pinjaman, tunggakan jasa administrasi pinjaman dan/ atau beban jasa administrasi pinjaman selanjutnya yang belum jatuh tempo dapat dihapukskan.

Pinjaman macet yang telah diupayakan pemulihannya, namun tidak berhasil terpulihkan, direklasifikasi menjadi kelompok aktiva lain-lain dengsn pos pinjaman bermasalah. Tata cara penghapusan pinjaman bermasalah tersebut akan diatur lebih lanjut oleh menteri BUMN. Pinjaman bermasalah yang telah dihapusbukuan harus telah diupayakan penagihannya. Apabila pinjaman bermasalah tersebut berhasil ditagih kembali, hasilnya dicatat dalam pos pinjaman bermasalah yang akan diterima kembali. Jumlah dan mutasi pos pinjamnan bermasalah yang diterima kembali harus dilaporkan secara periodik dalam laporan triwulan.

Pemindahbukuan pinjaman macet kedalam pos pinjaman bermasalah dapat dilaksanakan tanpa melalui proses pemulihan pinjaman apabila pinjaman macet tersebut terjadi karena keadaan memaksa (force majeure) sebagai berikut:

1. Mitra binaan meninggal dunia dan tidak ada ahli waris yang bersedia menanggung hutangnya.

2. Gagal usaha akibat bencana alam/ kerusuhan.

\section{KESIMPULAN DAN SARAN}

\subsection{Kesimpulan}

Berdasarkan hasil analisis data yang telah dilakukan maka dapat ditarik kesimpulan bahwa

1. Analisis sistem pemberian kredit pada unit program kemitraan bina lingkungan sudah sesuai dengan peraturan pemerintah yaitu pada peraturan menteri BUMN tertanggal 3 Juli 2015 dan pada Standar Prosedur Operasional Jasa Raharja unit Program Kemitraan Bina Lingkungan.

2. Sistem pemberian kredit dari flowchart yang ada sudah baik dimana dapat memberikan hasil yang baik bagi sitem pemberian kredit yang ada di PT Jasa Raharja Persero Sulut berdasarkan Standard prosedur Operasionalnya. Namun dalam realisasi dilapangan belum menunjukkan hasil yang maksimal karena masih banyak mitra binaan yang memiliki kredit macet dengan PKBL pembina yang ada di PT Jasa Raharja persero Sulut. 


\subsection{Saran}

Berdasarkan hasil penelitian mengenai Analisis Sistem Pemberian Kredit Program Kemitraan Bina Lingkungan Di PT Jasa Raharja Persero Sulut, maka penulis dapat memberikan saran sebagai berikut:

1. Bagi instansi terkait dalam hal ini PT Jasa Raharja Persero Sulut, analisis sistem pemberian kredit program kemitraan bina lingkungan di PT jasa Raharja Sulut sudah baik. Namun harus lebih diperhatikan lagi tentang bagaimana sistem penagihan kredit kepada mitra binaan, karena banyak terjadi kredit macet dan juga tidak adanya debtcolector yang menagih kredit macet sehingga keterlambatan itu serimng terjadi.Namun disamping itu sistemnya sudah begitu baik karena disesuaikan dengan Standar Prosedur operasional yang ada.

2. Bagi peneliti selanjutnya yang ingin melakukan penelitian agar lebih memperhatikan sistem analisis pemberian kredit agar supayasejalan dengan standar prosedur operasi dan juga lebih memperhatikan calon mitra binaan yang akan dibina agar supaya kedepannya tidak akan banyak terjadi kredit macet lagi.

\section{DAFTAR PUSTAKA}

Abiodun, Y.B. 2012 “The impact of CSR on firm's profitability in Nigeria

Amalia, Dewi. 2012 Analisis Reschedulling dan reconditioning piutang mitra binaan untuk meningkatkan kinerja keuangan PKBL di perum jasa Tirta. Jurnal Riset Mahasiswa Akuntansi. Universitas Kanjuruhan. http://ejournalukanjuruhan.ac.id

Archie B. Carroll, Kareem M Shabana The Business Case for Corporate Social Responsibility : A review of concepts research and practice. International journal of Management review. British Academy of Management

Bowen \& Carrol (1999;270) Corporate Social Responsibility

Indrawan, Rully dan Yaniawati, Poppy 2014. Metodologi Penelitian Kuantitatif dan Kualitatif, dan campuran untuk Manajemen, Pembangunan dan Pendidikan. PT. Refika Aditama. bandung

James M Reeve, Carl S. Warren, Jonathan E. Douchac, Novrys Suhardianto, Devi Sulistyo Kalanjati Amir Abadi Jusuf dan Chaerul D Djakman 2012 Principle of Accounting, Salemba Empat Cengage Learning Asia.

Kasmir. Dasar-Dasar perbankan. Revisi 2014 ed. Jakarta; PT Rajagrafindo Persada, 2016

Kieso, Donald E, Jerry j Weygant, and Terry D Warfield. Intermediate Accounting IFRS Edition 2 ed. USA; John WILEY,2014

Kementrian BUMN. Peraturan Menteri Negara Badabn usaha Milik Negara tentang program Kemitraan badan Usaha Milik Negara dengan usaha kecil dan program Bina Lingkungan. Permen BUMn no. PER-09/MBU/2015

Mudjiarto dkk 2015 Pembinaan Usaha Menengah, Kecil \& Mikro (UMKM) melalui program kemitraan dan bina Lingkungan BUMN PT Jasa Marga Persero cab Jagorawi. Jurnal abdimas volume1 nomor 2 Maret 2015

Rizki Putri Wulandari dkk 2016. Analisis pemberian Kredit untuk meminimalisir kredit bermasalah (Studi kasus pada divisi Community Development Center (CDC) PT Telekomunikasi Indonesia, Tbk, Sub Area Malang. Jurnal Administrasi Bisnis Vol.37 No 2 Agustus 2016

Sugiono, 2016. Memahami Penelitian Kualitatif. Alfabeta. Bandung

Wong, Tong, Takeuchi and George Corporate Social Responsibility an over and new research direction 